\title{
The relationship between capital structure and firm performance: evidence from Jordan
}

\author{
Khalaf Al-Taani \\ Department of Banking \& Finance, Faculty of Finance \& Administrative Sciences, Irbid National University, Irbid - Jordan
}

Email address:

ktaani@yahoo.com,Dr.ktaani@inu.edu.jo

\section{To cite this article:}

Khalaf Al-Taani. The Relationship between Capital Structure and Firm Performance: Evidence from Jordan. Journal of Finance and Accounting. Vol. 1, No. 3, 2013, pp. 41-45. doi: 10.11648/j.jfa.20130103.11

\begin{abstract}
The purpose of this study is to empirically investigate the relationship between capital structure and firm performance across different industries using a sample of Jordanian manufacturing firms in Jordan. The annual financial statements of 45 manufacturing companies listed on the Amman Stock Exchange were used for this study which covers a period of five (5) years from 2005-2009. Multiple regression analysis was applied on performance indicators such as Return on Asset (ROA) and Profit Margin (PM) as well as Short-term debt to Total assets (STDTA), Long term debt to Total assets (LTDTA) and Total debt to Equity (TDE) as capital structure variables. The results show that there is a negative and insignificant relationship between STDTA and LTDTA, and ROA and PM; while TDE is positively related with ROA and negatively related with PM. STDTA is significant using ROA while LTDTA is significant using PM. The study concludes that statistically, capital structure is not a major determinant of firm performance. It recommends that managers of manufacturing companies should exercise caution while choosing the amount of debt to use in their capital structure as it affects their performance negatively.
\end{abstract}

Keywords: Capital Structure, Firm Performance, Amman Stock Exchange, Jordan

\section{Introduction}

The theory of capital structure and its relationship with a firm's performance has been an issue of great concern in corporate finance and accounting literature since the seminal work of Modigliani and Miller (1958). They argue that under very restrictive assumptions of perfect capital market, investors' homogenous expectations, tax-free economy and no transaction costs, capital structure is irrelevant in determining firm value. Their subsequent preference of purely debt financing due to tax shield in 1963 was a contradiction to traditional approaches which suggests an optimal capital structure (Modigliani and Miller, 1963). In reality, establishing an optimal capital structure is a difficult task (Shoaib, 2011). He contends that a firm may require issuing a number of securities in a mixture of debt and equity to meet an exact combination that can maximize its value and having succeeded in doing so, the firm has achieved its optimal capital structure.

Jensen and Meckling (1976) demonstrates the amount of leverage in a firm's capital structure affects the agency conflicts between managers and shareholders and thus, can alter manager's behaviors and operating decisions. This position is agreed by Harris and Raviv (1991); Graham and Harvey (2001); Ebaid (2009). Since Jensen and Meckling's argument regarding capital structure influence on firm performance, several researchers have followed this extension and have conducted studies aimed at examining the relationship between capital structure and firm performance.

While the literature examining the performance implications of capital structure choices is immense in developed economies like USA and Europe, little is empirically known about such implications in emerging economies like Jordan. As Eldomiaty (2007) argues, capital market is less efficient and incomplete and suffers from higher level of information asymmetry than capital markets in developed countries. This research attempts to fill the gap in this field by investigating the effect of capital structure on corporate performance using different variables and a time frame that is considered most recent when compared with the researches reviewed in this work.

The objective of this study is to examine the impact capital structure has had on the performance of firms in Jordan. Specifically, it is aimed at: Examining the relationship between capital structure, and Return on Assets 
(ROA) and Profit Margin (PM). Data of 45 firms listed on Amman Stock Exchange (ASE) between 2005 and 2009, representing 225 - firm year observations would be used for the study. This study will be significant to managers in deciding the right combination of equity and debt to finance their operations and to maximize firm value at the same time contributing to the economic development of Jordan.

The rest of this paper is as follows: the next section presents related literature and followed by methodology. The third section discuses research results. Conclusion and recommendations for future researches discussed in the final section.

\section{Literature Review}

The literature on the relationship between firm performance and capital structure has produced mixed results. Some have been found a positive relation between financing choices and performance (profitability). Roden and Lewellen (1995) examines the capital structure of 48 US firms during the period 1981-1990 and revealed a positive relation between profitability and capital structure. Similar results were documented by Champion (1999) and Gosh et al. (2000). Hadlock and James (2002) suggest corporations with high level of profitability use high level of debts. In the other words, they show a positive relation between performance and capital structure. Abor (2005) reports a positive relation between capital structure, which measured by STD and TD, and performance over the period 1998-2002 in Ghanaian firms. Berger and Bonaccrsi di patti (2006) provide the same results. Finally, Arabiyan and Safari (2009) investigates the effects of capital structure on profitability using 100 Iranian listed firms from 2001 to 2007. They found short-term and total debts are positive related to profitability (ROE) while indicate a negative relation between long-term debts and ROE.

By contrast, several scholars revealed a negative relation between capital structure and performance. In this line, Kester (1986) found a negative relation between capital structure and performance (profitability) in the US and Japan. Similar results were reported by Friend and Lang (1988), Rajan and Zingales (1995) in the G-7 countries. In addition, Huang and Song (2006) found a negative correlation between leverage and performance (earnings before interest and tax to total assets) in China firms.

Several studies show either poor or no statistical relation between capital structure and performance (Tang and Jange, 2007; Ebaid, 2009). Ebaid (2009) investigates the impact of capital structure choice on performance of 64 firms from 1997 to 2005 in the Egyptian capital market. He employs three accounting -based measures; including ROA, ROE and gross profit margin, and concludes capital structure choices, generally, has a week-to-no impact on firm performance.

Capital structure literature has shown conflicting results among researchers. Some studies have shown that capital structure has significance impact on firm performance while others have shown no impact. Generally, researchers agree that an association between capital structure and firm performance exist (Hung, et. al. 2002). While some studies have concluded that the relationship between capital structure and firm performance is both positive and negative (Tsangaao, et. al. 2009; Saeed and Mahmoodi, 2011; Abor, 2005; Oke and Afolabi, 2008) others concluded that the relationship is negative (Narender, et. al. 2007; Pratheepkanth, 2011; Shah, et. al. 2011; Onaolapo and Kajola. 2010; Shoaib, 2007). Yet, other studies have documented a positive relationship (Shoaib and Siddiqui, 2011; Aman, 2011; Chowdhury, 2010; Omorogie and Erah, 2010).

With these mixed and conflicting results, the question for examining the relationship between capital structure and firm performance has remained a puzzle and empirical study continues.

\section{Objectives}

The focus of this study is Impact of Capital structure on Performance of the Business industry in listed companies in Jordan.

- To reveal the impact of capital structure on financial performance.

- To evaluate the interrelationship between capital structure and performance.

\section{Hypotheses}

The following hypothesis is formulated for the study

$\mathrm{H} 0$; - There is a negative relationship between capital structure and financial performance.

H1:- The capital structure has significant impact on financial performance.

H2: - There is a positive relationship between capital structure and financial performance.

\section{Data and Methodology}

To produce the above mentioned research objective, the data for this study was gathered from the financial statements as published by Business Companies. In addition, another source of data was through reference to the review of different articles, papers, and relevant previous studies. For this purpose, collecting data of Business firms is used which are listed on Amman Stock Exchange. All firms are taken for the study representing the period of 2005-2009, and the average values of each item was considered for the purpose of ratio computation and analysis. The population of the study is made up of the 45 manufacturing companies listed on ASE.

The data obtained from these companies were tabulated and analyzed using multiple regression models. This statistical technique is used because the study seeks to establish if there is a relationship between capital structure 
and firm performance.

\subsection{Definition of Variables}

- $\quad$ Short term debt to total assets (STDTA): This is an independent variable. It is derived by dividing short term debt by total assets.

- $\quad$ Long term debt to total assets (LTDTA): This is also an independent variable. It is derived by dividing long term debt by total assets.

- Total debt to equity (TDE): This is another independent variable. It is calculated by dividing total debt by equity.

- Return on assets (ROA): This is a dependent variable. It is the quotient of dividing profit after tax by total assets.

- $\quad$ Profit margin (PM): This is also a dependent variable. It is the quotient of dividing profit after tax by turnover.

\subsection{Model Specification}

The researcher adopts the model used by Shoaib (2007) and Onaolapo and Kajola (2010) with little modification to suit the researcher's need. The model is as follows:

$\mathrm{CS}=\mathrm{f}($ STDTA, LTDTA, TDE)

$\mathrm{PERF}=\mathrm{f}(\mathrm{CS})$, by expansion,

PERF $=\mathrm{f}($ STDTA, LTDTA, TDE).

Using multiple regression analysis, the model can be built as follows:

PERF $=$ b0 + b1 STDTA + b2 LTDTA + b3 TDE + e

Where,

$\mathrm{PERF}=$ performance (proxy by ROA, PM)

ROA $=$ Return on Asset

$\mathrm{PM}=$ Profit Margin;

$\mathrm{CS}=$ Capital Structure;

STDTA = Short term debt to total assets;

LTDTA $=$ Long term debt to total assets;

TDE $=$ Total debts to equity;

$\mathrm{B} 0=$ the constant, and

$\mathrm{B} 1, \mathrm{~b} 2, \mathrm{~b} 3$, are regression coefficients.

\section{Results and Discussions}

Table 1. Regression Result

\begin{tabular}{lllllll}
\hline Variable & Coefficient & T-Stat & Sig & VIF & R-square & Sig f- change \\
\hline Constant & 7.438 & 4.339 & 0.000 & - & 0.039 & 0.032 \\
STDTA & -0.123 & $-2.400^{*}$ & 0.17 & 1.070 & \\
LTDTA & -0.150 & $-2.133^{*}$ & 0.034 & 1.467 & & \\
TDE & 0.004 & 0.757 & 0.450 & 1.466 & & \\
\hline
\end{tabular}

Dependent variable: ROA: SOURCE; SPSS Statistics

The table above shows the regression result used to verify the association between STDTA, LTDTA, TDE and ROA. The result indicates a negative relationship between STDTA, LTDTA and ROA while a positive relationship exists between TDE and ROA. This means an increase in STDTA and LTDTA by one will reduce ROA by $12.3 \%$ and $15 \%$ respectively while a unit change in TDE will increase ROA by $0.4 \%$. R2 is $4 \%$ which indicates highly insignificant relationship between the variables, as $96 \%$ of the variation is attributable to factors outside this study. VIF is less than 5 which means the independent variables are not too inter-correlated. The t-stat is within -2.20 and + 2.20 except that of TDE which is outside the range of the critical value of $t$ at $5 \%$ level of significance. Consequently, the null hypothesis is accepted using long term debt to total assets and short term debt to total assets leading to the conclusion that capital structure does not significantly affect firm performance (ROA). However, using total debt to equity, the null hypothesis is rejected. Hence, there is a significance relationship between capital structure (TDE) and performance (ROA).

Table 2. Regression Result

\begin{tabular}{lllllll}
\hline Variable & Coefficient & T-Stat & Sig & VIF & R-square & Sig f-change \\
\hline Constant & 2.308 & 0.396 & & & 0.019 & 0.235 \\
STDTA & -0.028 & -0.160 & 0.873 & 1.070 & \\
LTDTA & -0.392 & -1.641 & 0.102 & 1.468 & \\
TDE & -0.003 & -0.140 & 0.889 & 1.466 & & \\
\hline
\end{tabular}


The table above represents the result of regression used to verify the relationship between STDTA, LTDTA, TDE and PM. The result indicates a negative relationship between STDTA, LTDT, TDE and PM. This means an increase in STDTA, LTDTA, and TDE by one will reduce PM by $2.8 \%, 3.92 \%$ and $0.3 \%$ respectively. R-square is $20 \%$ which means $80 \%$ of the variation is attributable to factors outside this study. VIF is less than 5 and this means the independent variables are not too inter-correlated. The null hypothesis which states that capital structure does not significantly affect firm performance variable, profit margin is accepted for STDTA, LTDTA and TDE. The findings of this work are consistent with Shoaib, 2007; Onaolapo and Kajola, 2010; Shah, al.2011; Pratheepkanth, 2011; and Narendar, 2011.

\section{Conclusion}

This study examines the impact of capital structure on firm performance. Base on the selected sample size and using capital structure indicators like STDTA, LTDTA and TDE as well as ROA and PM as performance indicators, generally, there is a negative and insignificant relationship between capital structure and firm performance. The study concludes that statistically, capital structure represented by short-term debt to total assets (STDTA), long- term debts to total assets (LTDTA) and total debt to equity (TDE) is not a major determination of firm performance.

Although, the study has found no statistically significant relationship between capital structure and firm performance, the study recommends that managers should be careful while using debt as a source of finance since a negative relationship exist between the capital structure and performance variables used in this work. They should try to finance their activities with retained earnings and use debt as a last option as supported by the pecking order theory.

\section{References}

[1] Abor, J. (2005). The effect of capital structure on firm performance: an empirical analysis of listed firms in Ghana, Journal of Risk Finance, Vol.2, pp438-447.

[2] Aman, S. (2011). Ownership structure and corporate performance: evidence from India, International Journal of Humanities and Social Sciences, Vol. 1(1), pp23-29.

[3] Arbabiyan, Ali-Akbar and Safari, Mehdi, (2009). The effects of capital structure and profitability in the listed firms in Tehran Stock Exchange, Journal of Management Perspective, Vol. 33, pp. 159-175.

[4] Berger, A. and Bonaccorsi di Patti, E.,(2006). Capital structure and firm performance: a new approach to testing agency theory and an application to the banking industry, Journal of Banking and Finance, Vol. 30,pp.1065-102.

[5] Chowdhury, A. and Chowdhuy, P. S. (2010). Impact of capital structure on firm's value: evidence from Bangladesh, Peer reviewed and open access journal, Vol. 3 (3), pp 111-115.

[6] Champion, D., 2010. Finance: the joy of leverage, Harvard Business Review, Vol. 77, pp. 19-22.

[7] Ebaid, I. E. (2009). The impact of capital structure choice on firm performance: empirical evidence from Egypt, Journal of risk Finance, Vol. 7, pp 477-487.

[8] Eldomiaty, T. (2007). Determinants of corporate capital structure: evidence from an emerging economy, International journal of commerce and management, Vol. 17, pp 25-43.

[9] Friend, I. and Lang, L., (1988). An empirical test of the impact of managerial self-interest on corporate structure, Journal of Finance, Vol. 43, pp. 271-81.

[10] Graham, J. and Harvey, C. (2001). The theory and practice of corporate finance: evidence from the field, Journal of Financial Economics, Vol. 50, pp187-243.

[11] Ghosh, C., Nag, R. and Sirmans, C., (2000). The pricing of seasoned equity offerings: evidence from REITs, Real Estate Economics, vol. 28, pp. 363-84.

[12] Hadlock, C. and James, C., (2002). Do banks provide financial slack?, Journal of Finance, Vol. 57, pp. 1383-420.

[13] Huang, S. and Song, F., (2006). The determinants of capital structure: evidence from China, China Economic Review, Vol. 17 No. 1, pp. 14-36.

[14] Harris, M. and Raviv, A. (1991). Capital structure and information role of debt, Journal of Finance, Vol. 46, pp279355.

[15] Hung, C. Y., Albert, C. P. C. and Eddie, H. C. M. (2002). Capital structure and profitability of the property and construction sectors in Hong Kong, Journal of Property Investment and Finance, Vol. 20(6), pp434-453.

[16] Jensen, M. and Meckling, W. (1976). The theory of the firm: management behavior, agency costs and capital structure, Journal of Financial Economics, Vol. 3(1), pp 305-360.

[17] Kester, W., (1986). Capital and ownership structure: a comparison of United States and Japanese manufacturing corporations, Financial Management, Vol. 15, pp. 5-16.

[18] Modigliani, F. and Miller, M. (1958). The cost of capital, corporation finance and theory of investment, American Economic Review, Vol. 48, pp 261-297.

[19] Modigliani, F. and Miller, M. (1963). Corporate income taxes and the cost of capital: a correction, American Economic Review, Vol. 53, pp 443-453.

[20] Narendar, V. R., Khamis, H. M. and Lateef, A. S. (2007). Capital structure and financial performance: evidence from Oman, Indian Journal of Economics and Business. Vol. 2, pp $57-65$.

[21] Oke, O. O. and Aolabi, B. (2008). Capital structure and industrial performance in Nigeria, Journal of Social Science, Vol. 4(1), pp 13-21.

[22] Omorogie, A. N. and Erah, D. O. (2010). Capital structure and corporate performance in Nigeria: an empirical investigation, AAU Journal of Management Sciences, Vol. 1 (1), pp 43-52. 
[23] Onaolapo, A. A. and Kajola, S. O. (2010). Capital structure and firm performance: evidence from Nigeria, European Journal of Economics, Finance and Administrative Sciences, Issue 25, pp 70-77.

[24] Pratheepkanth, P. (2011). Capital structure and financial performance: evidence from selected business companies in Colombo Stock Exchange, SriLanka, Journal of arts, Science and Commerce, Vol. 2(2), pp 171-173.

[25] Rajan, R. and Zingales, L., (1995). What do we know about capital structure decisions: some evidence from international data, The journal of Finance, Vol. 50, pp. 142-60.

[26] Roden, D. and Lewellen. W., (1995). ). Corporate Capital structure decisions: evidence from leveraged buyouts, Financial Management, Vol.24, pp. 76-87.
[27] Saeedi, A. and Mahmoodi, I. (2011). Capital structure and firm performance: evidence from Iranian Companies, International Research Journal and Economics, Vol. 70, pp 20-26.

[28] Siddiqui, M. A. and Shoaib, A. (2011). Measuring performance through capital structure: evidence from banking sector of Pakistan, African Journal of Business Management, Vol. 5(5), pp 1871-1878.

[29] Tsangaao, C., Kuei-Chiu, L., Yao-Men, Y. and Chia-Hao (2009). Does capital structure affect operating performances of credit cooperatives in Taiwan: application of panel threshold method, International Research Journal of Finance and Economics, Vol. 32, pp18-21? 